\title{
Talent Management as Success Factor for Organizational Performance: A Case of Pharmaceutical Industry in Pakistan
}

\author{
Muhammad Umair Abbasi* \\ HR Project Consultant for USAID projects \\ Muhammad Sohail" \\ Biogenic Pakistan Private Limited, Karachi. \\ Farooq-E-Azam Cheema* \\ Institute of Business \& Technology (IBT), Karachi. \\ Nadeem A. Syed \\ FAST Business School, National University, Karachi.
}

\begin{abstract}
Purpose - The purpose of this study is to illuminate the importance of Talent Management Practices for the Pharmaceutical Industry in Pakistan and to impose the organizations for the development and implementation of TM mechanism in the industry that provide tools for achieving sustainable competitive advantages in today's highly competitive environment.

Methodology/Sample - Data from the targeted pharmaceutical organizations were mostly obtained personally by researchers through survey questionnaire and structured interviews. The focus of interviews related to top management personnel, human resource experts and professionals according to availability. Findings - The main findings from this research are that talent management practices will definitely increases the performance of the organization. To be successful and gain sustainable edge recommended that organizations must keep eye on their people and take care of them in all manners. This process needed special attention as much as goals of the organization because the talented people are definitely the most valuable asset for an organization. Practical Implications - The essential features to compete and survival in the highly competitive environment the talent plays a vital role in the achievement of an organization's overall strategic objectives and visibly illustrates that the TM practices fully understands and supports the direction in which the organization is moving.

Research Limitations - Data confidentiality policy of organizations, time constraint and unavailability of concerned personnel at the time of interviews were limitations in some cases while gathering data.
\end{abstract}

Keywords : Valuable Assets, Career Planning, Competitive Edge, Talent Management, Performance Management

\section{BACKGROUND OF THE STUDY}

Today's markets have become global and highly competitive. And, therefore, it has become essential for the survival of the firms they become adaptive and responsive to change around them. They need to strategize in order for them to deliver excellence in *The material presented by the author does not necessarily portray the viewpoint of the editors and the management of the Institute of Business \& Technology (IBT) or USAID projects, Biogenic Pakistan Private Limited, FAST Business School, National University, Karachi.

*Muhammad Umair : umairabbasi@ymail.com

* Muhammad Sohail : m.si1@live.com

*Farooq-E-Azam Cheema : dr.cheema@live.com

* Nadeem A. Syed : nadeem.syed@nu.edu.pk

C JMSS is published by the Institute of Business and Technology (IBT). Main Ibrahim Hydri Road, Korangi Creek, Karachi-75190, Pakistan. 
their services and products that can attain a competitive edge with their clientele (Deros, et al., 2008). In essence, the talented people are an asset for any organization and behind the success of the organizations.

To achieve this end, the organizations need to be rich in qualified human resources. They need to develop and implement effective HR functions including method of attracting, deploying, retaining and motivating competent workforce. Thus, a term "Talent Management" has been introduced in the recent past in order to offer one window solution for all problems attracting and retaining the competent human resources and developing them for future. Professionally implemented talent management program not only benefits the organizations, it also benefits the workforce. It paves way for their growth and offers then avenues for forward movement along their career ladder. It leads to increased efficiency and enthusiasm among them while on job and promotes their employability. The employees who are part of talent management program are likely to be more innovative and contributing effectively in the success of the organization.

The concept of Talent management is not new globally and it is apparent that the organizations have always relied upon the human resources for attaining competent edge over the competitors. In the labour market, larger organizations have been continually rivaling for talent as well. In 1998, United States largest and most prestigious management consulting firm McKinsey \& Company originated the term "The War for Talent" as the name for their original research on talent management practices, concepts and beliefs. It referred to an increasingly competitive landscape for recruiting and retaining talented employees. Organizations realized that they had already been experiencing war for talent but that had not really been making proper use of it.

In the old way organizations believed that having good people is one of many important tools for achieving better performance but after the concept of talent management most of the organizations believed that having the right talent throughout the organization is a critical source to gain competitive advantage as well. As the global economy expanded dramatically business leaders and human resource professionals worried about the intensifying competition for talent; the impact of not having the right people for the right job put the otherwise technically sound organizations in defensive positions vis-à-vis their competitors.

\subsection{Aim of the Study}

In countries like Pakistan overall focus on human resource development is inadequate. They do not believe in routine formalized HR functions even let alone the talent management like contemporary specialized HR functions. Due to high unemployment outside, they do not believe that they really needed a specialized HR function in their organizations since the basic functions like attracting the employees, retaining them and developing them for future lose significance in wake of high unemployment outside. Accordingly, local private sector organizations hardly undertake any formal talent management program.

However, certain multinational corporations operating in Pakistan are necessarily practicing talent management programs. So the purpose of this study is to highlight the format of talent management programs in these multinational organizations and benefits of these programs to the organizations and to present the model to the local sector organizations to emulate. For that purpose, four pharmaceutical firms Martin Dow Pharmaceuticals Limited, Novo Nordisk Pharma Private Limited, Genix Pharma Private Limited, and Sante Private Limited were randomly chosen who are practicing the talent management program sufficiently. To undertake the study data was collected from the employees of the HR departments and Talent Management Departments and the senior members of the organizations. 


\subsection{Research Questions}

In order to address the objectives of the study, following research questions were developed in survey questionnaire for the answers.

1. What are the reasons to implement talent management program in Pharmaceutical Industry in Pakistan?

2. How talent management programs are linked with other HR management functions?

3. What approaches are adopted to implement talent management programs in Pharmaceutical Industry in Pakistan?

4. How the pharmaceutical industries in Pakistan describe the talent management programs?

5. What are characteristics of talent management programs that result in improving organization performance?

\section{LITERATURE REVIEW}

In today's business environment characterized with competition, every organization has no option but to grow for thriving. The human resources are being increasingly seen as the difference creators especially in the days to come. For instance, Coetzee (2004) says that the supreme importance to the success of an organization's objectives is to recruit and develop the talented staff, talent is always create value and success for an organization. Human capital concept is the latest concept that emphasizes the human resources performance crucial to the organizational performance. The concept emphasizes that firm's knowledge capital depends upon the human capital itself who are the main instrument for achieving competitive advantage for the organizations (Odonez de Pablos, 2004).

In their book The War for Talent published in 2000 the McKinsey and Company authors argue that companies are now realizing that talent management mechanism is one of the important factor for sustainable competitive edge and it is as least as important to make managers responsible for increasing their talent pool as it is to hold them accountable for their budget. In increasing numbers they are making the link between talent management and organization performance and making the building of talent a priority. Accordingly, savvy managers are putting extra premium on quality of their workforce. For that purpose they are going extra mileage to develop them. Talent management program is one of the HRD measures that the good organizations of the contemporary day are taking. The program entails helping the organization recruit and retain competent talented employees.

An organization that does not undertake planning on talent management program, they may face the issues of employee turnover and bear the direct and indirect costs thus incurred on having new employees and then preparing them to work. If organizations are truly willing to win the war for talent, then they need, in particular, to keep finding, nurturing and developing extraordinary people, they must develop a capacity to develop new approaches to talent management (Powell and Lubitsh, 2007).

It seems to be difficult to formulate an appropriate right definition and concept for talent management as Lewis and Heckman (2006) say that talent management has no clear meanings. However, certain writers have tried to define it. Byham (2001) says that talent management is a combination of typical human resource department practices activities expert areas such as recruiting, selection, deploying, development, retention, career progression and succession management. According to (Van Dijk, 2008), talent 
management is a systematic process that describes dynamic interaction between many functions and processes. Talent management is about attracting, identifying, recruiting, developing, motivating, promoting and retaining people that have a strong potential to succeed within an organization and definitely increases the performance of the organization.

To summarize, talent management is a systematical approach of human resource management that formalizes the mechanism of sourcing (finding talent), screening (sorting of qualified and unqualified candidate), selection (evaluation/testing, interviewing), onboarding (offer/acceptance, medical/security clearance), deploying (assignments, role and responsibility), and retention (keep the talent that contributes to the success of the organization); through motivation (increase the level of enthusiasm), career progression (series of career success) and succession planning (developing alternate).

Succession planning is the first apparent fruit of talent management. The succession planning is to check the existing human resources strengths, and linking these to anticipate for future needs (Elliot, 1998). It focuses on developmental processes of the individual workers to prepare an heir for the key positions (Elliot, 1998; Leibman, et al. 1996). Its main goal, at the end, is create strong leadership teams and diminish uncertainty in terms turnover.

The impacts of talent management practices on organizational performance have led to a number of studies which associated the impact of HR practices to firm outcomes. All businesses need a wide variety of people with the most potential to deliver new sources of competitive advantage. In order to create and sustain a culture of excellence, having a comprehensive talent management system is the key of success. Chambers, et al. (1998) wrote that organizations need to elevate talent management to a burning corporate priority. Talent management needs to be seen as essential for achieving the organization's goals and objectives if it mange properly in a comprehensive way.

So, accordingly, investment in various HR practices have been linked to firm's business performance such as: training (Russell, Terborg and Powers, 1985), selection and staffing (Terpstra, Rozell, 1993), appraisal (Borman, 1991), and compensation (Gerhart and Milkovich, 1992). Organizations will need to develop formalized and effective policies and practices across all of the primary human resource areas. In order to effectively recruit and retain scarce labor, organizations need to create and perpetually refine employee value proposition organizations that are able to successfully recruit and retain valued employees (Ashton and Morton, 2005).

\section{RESEARCH METHOD}

The research comprised both primary and secondary data. Primary data was collected through questionnaires and interview. For this study, four pharmaceutical firms Martin Dow Pharmaceuticals Limited, Novo Nordisk Pharma Private Limited, Genix Pharma Private Limited, and Sante Private Limited were randomly chosen. All these firms are located in Karachi. Simple criteria of selection the firms was that they practice talent management function.

In these firms, sixty five people coming from the HR department, Talent Management department, and senior management members were selected for questionnaire data while ten people from four firms belonging to above mentioned departments especially at the middle and senior level management were selected for interviewing. All sixty five people selected were administered questionnaire through e-mail along with an introductory covering letter explaining the grounds behind the survey and pledge to the respondents maintaining confidentiality and privacy.

A comprehensive questionnaire was developed for survey, based on following 5 sub-areas of the study contained in the five research questions. The items in each of the 
five sections were measured on given category scale ranging from strongly disagreed, disagreed, neutral to agreed and strongly agreed. Selected individuals were personally approached through face to face meetings to request their earnestness in responding the questionnaire. Despite this hard work just 53\% response could be elicited.

Besides administering questionnaire, 10 face-to-face interviews were also conducted with HR Managers, Assistant HR Managers and top management personnel of targeted pharmaceutical organizations.

\section{RESULTS}

\subsection{Reasons of Talent Management practices adopted in Pharmaceutical Industry in Pakistan}

For this part of study, questionnaire carried questions on six reasons for having adopted the talent management program by the target organizations. Those reasons were related to improvement in performance, greater diversity in management, growth of the future leaders, to manage internal talent effectively and improving employee retention rate. Response of the sample employees is integrated in Figure 2 below that shows that people mostly agreed with the reasons for initiation of the talent management program in the firms.

Figure 1

Reasons of Talent Management practices are used in Pharmaceutical Industry in Pakistan

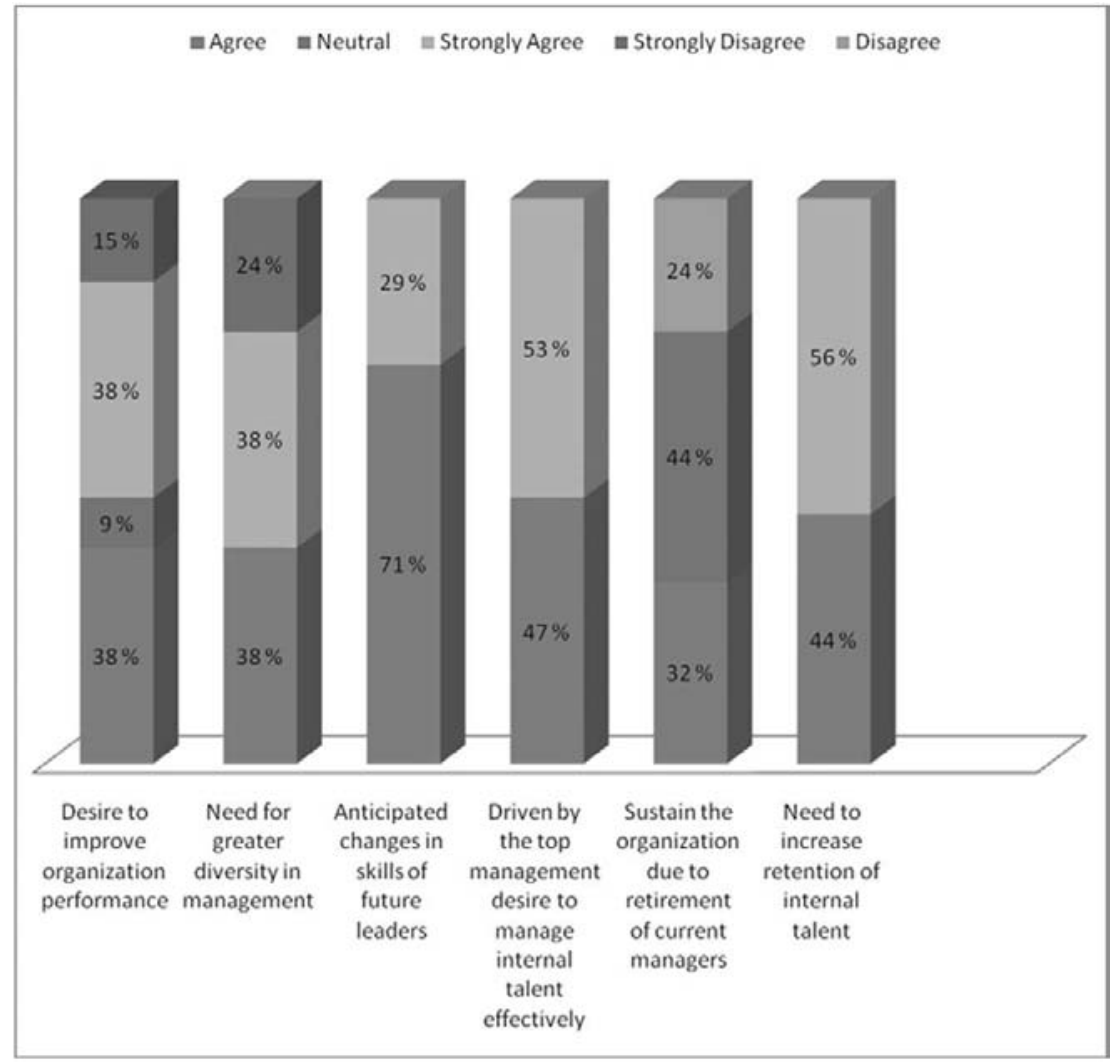




\subsection{Link between Talent Management functions with the rests of the HR functions.}

In this part of the questionnaire, questions were asked to identify link of talent management functions with other rests of the HR functions like performance management, career planning, HR planning, recruitment and selection, compensation and management development. Data is integrated in the Figure 2 below. Findings show 83 percent respondents agreed that talent management practices are linked with performance management, career planning, compensation \& benefits, whereas 18 percent were not recorded their perceptions. 97 percent respondents agreed that recruitment \& selection is integrated with talent management practices while remaining 3 percent respondents remained neutral. 76 percent respondents agreed and 24 percent remained neutral regarding link between talent management and management development programs in their organization.

Figure 2

Link between Talent Management practices and other HR functions

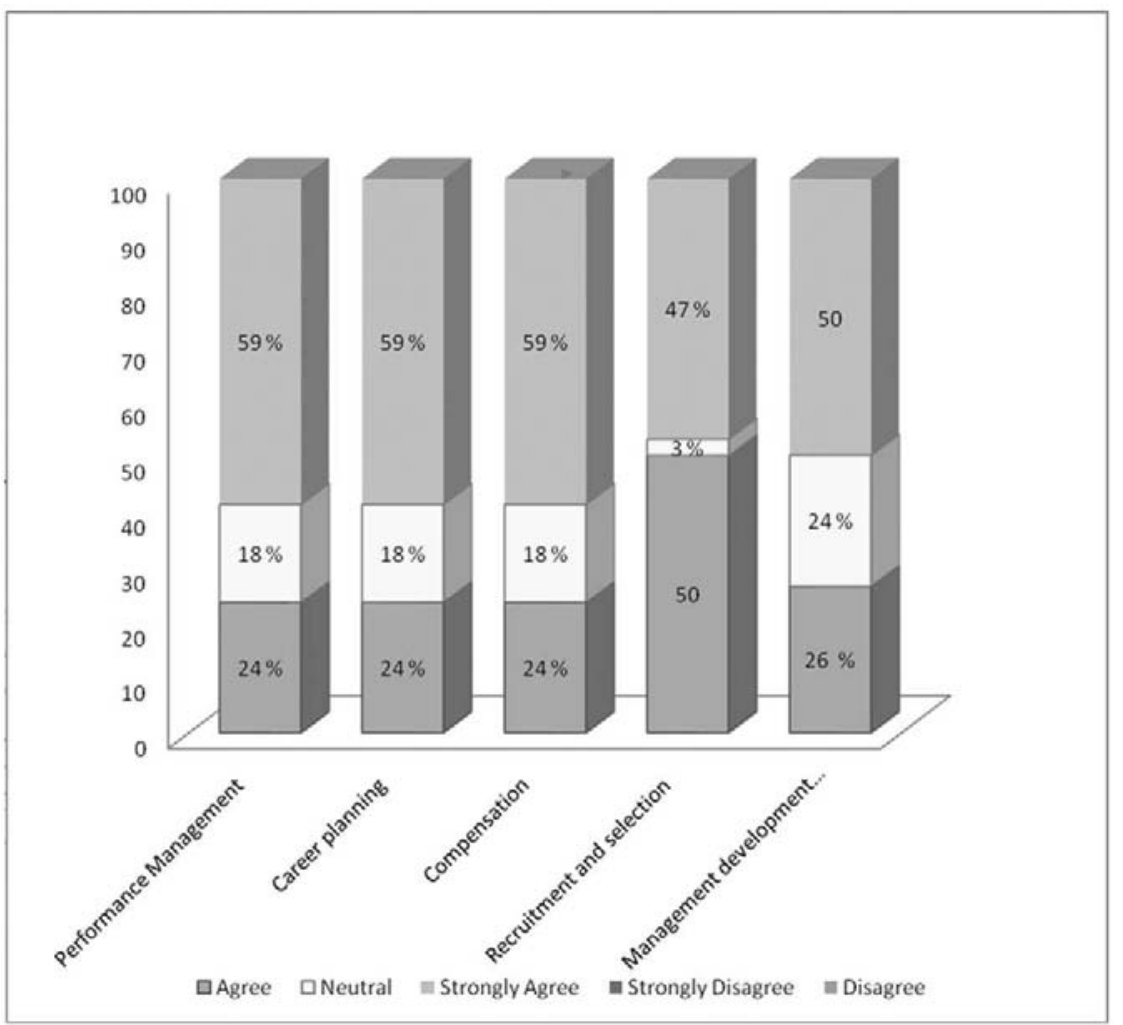

\subsection{Approach towards Talent Management by the Pharmaceutical Industry in Pakistan}

This part of the questionnaire asked the respondents about how the pharmaceutical industry as a whole takes the talent management. The areas to vote among others were; as a tool of realizing business strategy, enhancing organizational performance, promoting and share ownership across the organization, involving line managers, filling the future positions, grooming the staff for future etc. The data are integrated in Figure 4 below. Findings are self-explanatory. Regarding most $f$ the areas, majority of the respondents expressed their agreement. It means pharmaceutical sector as a whole takes the talent management very positively and comprehensively. 
Figure 3

The approaches towards Talent Management by Pharmaceutical Industry in Pakistan

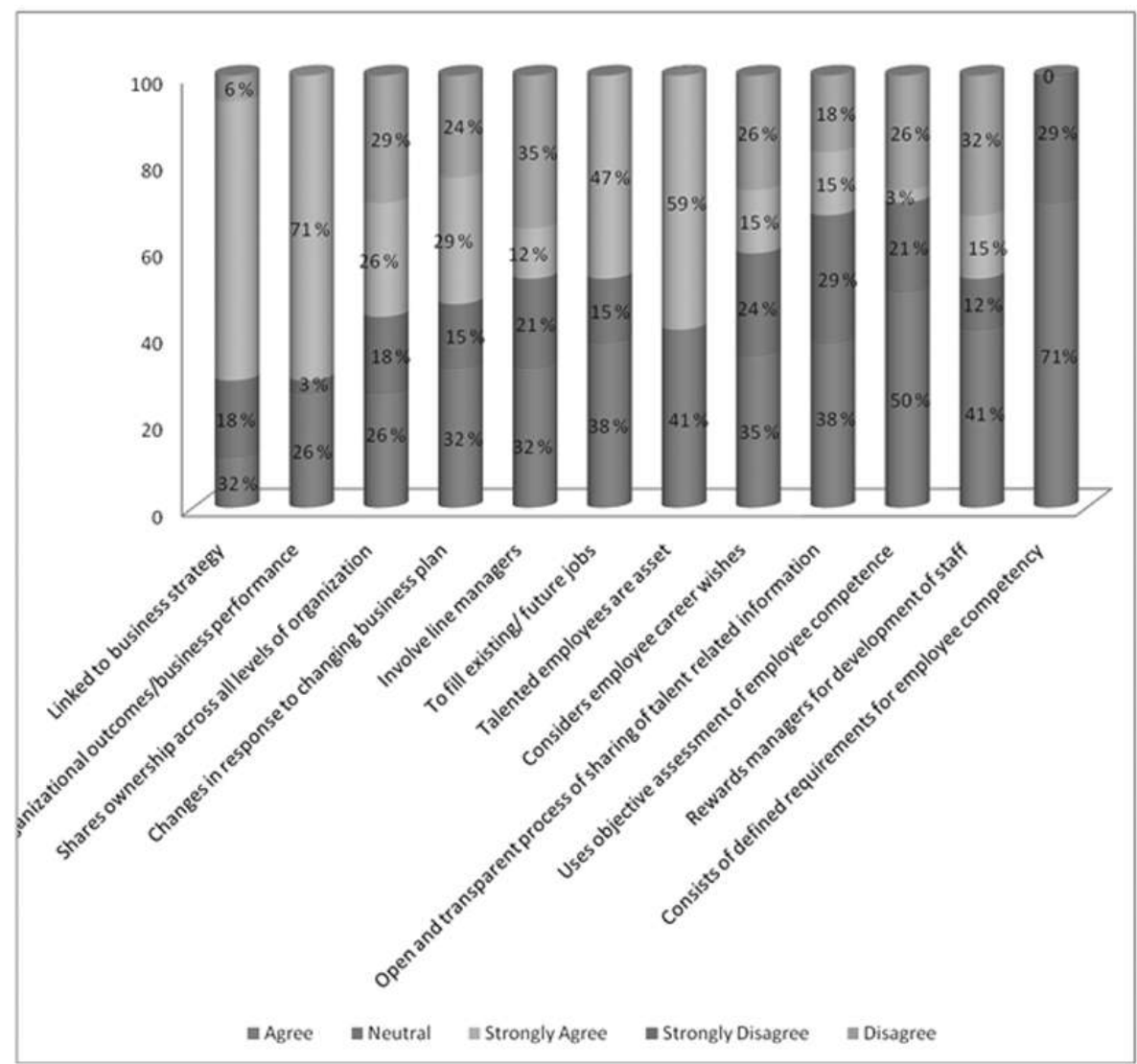

\subsection{How Talent Management Program are described in the target organizations}

In this area of study, 76 percent respondents said that talent management practices entail productive rules and procedures which enhance people's performance as well. 56 percent respondents said that it is the parent department that is responsible for talent management practices whereas 29 percent strongly disagreed with that statement and believed that it is the HR/Talent Management Department that is responsible for it. 79 percent respondents agreed that without involvement of the top management, talent management cannot be practiced but 21 percent disagreed. 74 percent agreed to the statement that their department heads are evaluated on account of their role in talent management and they are rewarded on good performance in this area, 26 percent, however, disagreed.71 percent respondents agreed to the statement that in their organizations promotion is based on past performance. 53 percent respondents believed that members of talent management team in their organization are competent and credible but on other side 35 percent people disagreed. 84 percent respondents agreed that senior management spend significant time on talent management. Data gathered in this area is integrated in Figure 5 below. 
Figure 5

Talent Management practices described in Resondent Organizations

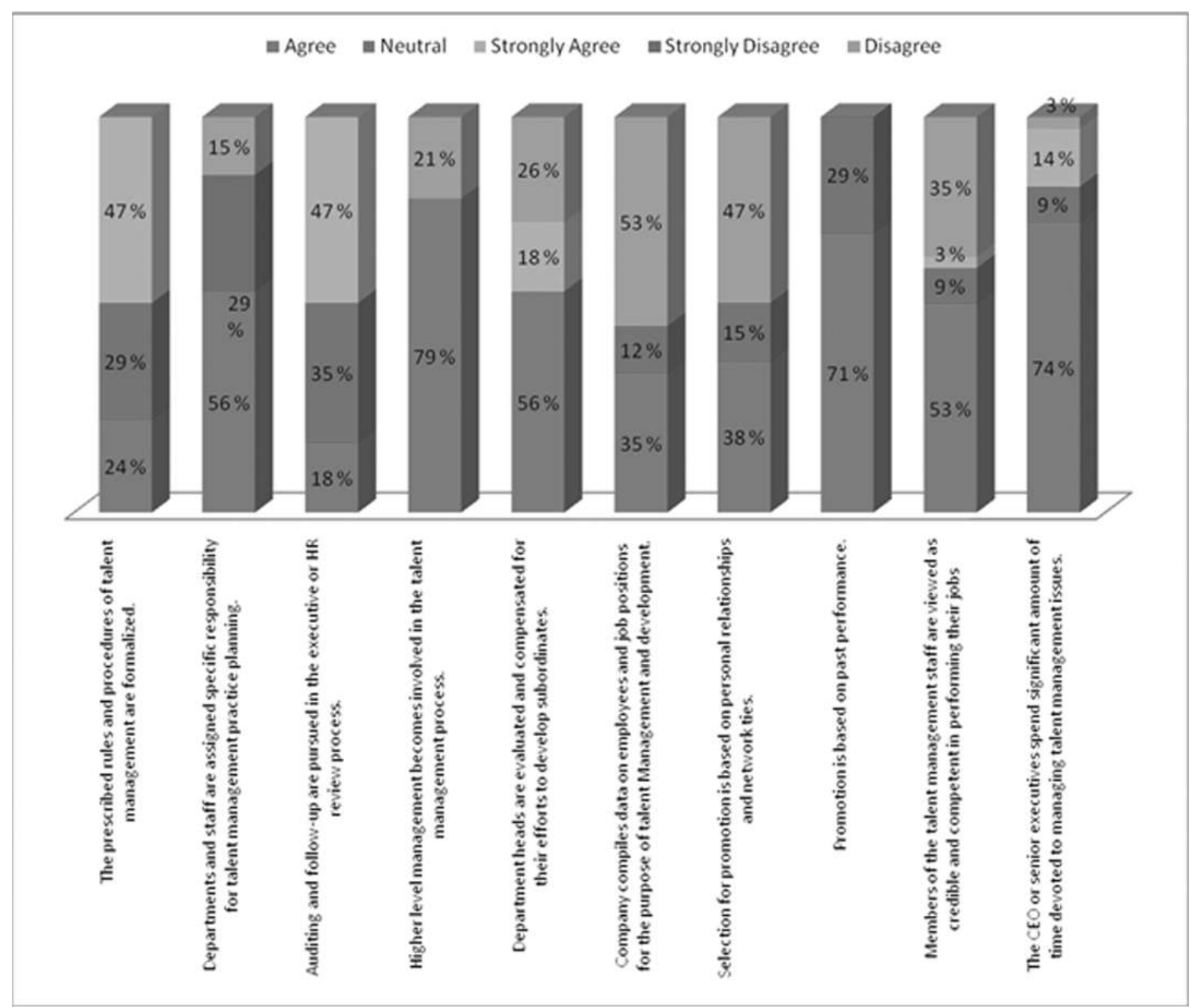

\subsection{Charachteristics of Talent Management Programs that lead to better performance}

Majority of the respondents agreed with the statements underlying role of talent management schemes in improving current and future performance of the employees. For instance, 94 percent respondents agreed to the statement that talent management practices established a means to measure individual performance that is aligned with the competencies currently demonstrated by successful performers. Similarly, 91 percent respondents agree that talent management practices determine what performance is needed in the future by establishing future competency models for all job categories. Likewise, 88 percent respondents agreed that talent management practices established a means by which to narrow the gaps through the use of individual development plans (IDPs). Data is integrated in the Figure 6 below. 
Figure 5

Charachteristics of Talent Management practices

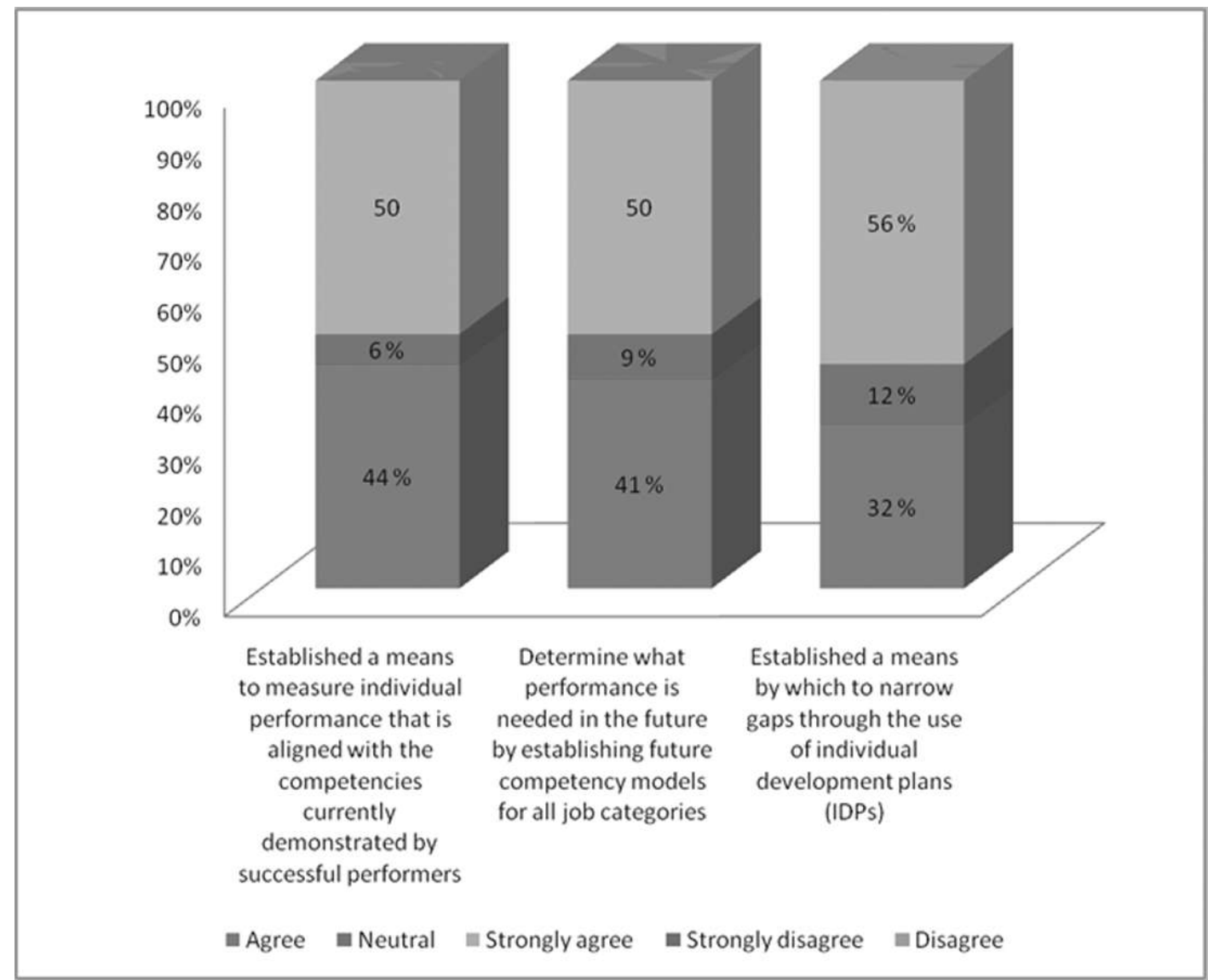

\section{CONCLUSION}

The study was aimed at investigating the various dimensions relating to talent management programs. For this purpose, four pharmaceutical organizations were selected from the pharmaceutical industry of Pakistan based in Karachi. The study evaluated each of the factors and established to what extent the approaches that organizations adopted towards talent management. Findings of the study showed that talent management programs are being run in these organizations very successfully. This study also relayed a message to the Pakistani organizations that talent management practices is no more an alien practice in this culture rather it can be used as an effective tool of employee attraction, retention, development and increases the performance of organizations in a highly competitive environment.

Another related area found in this study that talent management would anticipate human resource activities such as recruitment planning, recruitment and selection, coaching, mentoring, learning and development, performance management as well as compensation and reward management. Through these activities, careful planning to the organization's overall business strategies needs is required for talent management to become ingrained 
in an organization's traditions and practices. The findings in this study also show that if talent management is given appropriate attention through developing employees' skills and enriching their jobs does, it enhances the employees' current and future performance. Furthermore, the study revealed that talent management is not only individually targeted activity but also fully integrated with the organizational performance.

This research and the previous studies revealed that it is not the capital or money that is the most important property for the organization today rather it is the intellectual property that is the asset for the organizations. Accordingly, given the research findings, developing talent is key to an organization's success. Organizations depend on a talented pool to accomplish the organizational sustainability and competitive advantage for the future. Therefore, it is important for human resource practitioners in conjunction with the top management to address the talent imperatives, aligning them with the business strategy and taking a systematic approach to meeting these imperatives both on short as well long term basis.

\section{REFERENCES}

1. Ashton, C. and Morton, L. (2005) Managing talent for competitive advantage. Human Resources Strategic Review, 4(5), 28 - 31

2. Borman, W. C. (1991) Job Behavior, Performance and Effectiveness. Handbook of industrial and organizational psychology, (2), 271 - 326

3. Byham, W. C. (2001) Are leaders born or made? Workspan, 44(12), 56?60.

4. Chambers, E.G., Foulton, M., Handfield-Jones, H., Hankin,S.M. \& Michaels, E.G. (1998) The war for talent. The McKinsey Quarterly, 3, 44-57.

5. Coetsee L.D, (2004) Peak Performance and Productivity: A practical guide for creation of a motivating climate. 2nd edition Potchefstroom: Ons drukkers

6. Deros B., Rahman M., Ismail A.R and Said A. H, (2008) A survey of Benchmarking Understanding and Knowledge among Malaysian Automotive Components Manufacturing SMEs. European Journal of Scientific Research, (33)3:385-397.

7. Elliott, S. (1998) Recruiting for Success: Hiring and Keeping the Right Management, APQC, Houston: TX.

8. Gerhart, B. and Milkovich, G. T. (1992) Employee compensation: Research and practice. Handbook on industrial and organizational psychology, 3, 481 $-569$

9. Lewis R.E and Heckman R.J, (2006) Talent management - A critical review. Human Resources Management review, (16)2: 139-154.

10. Leibman, M., Bruer, R. and Maki, B.R. (1996) Succession management: the next generation of succession planning. Human Resources Planning, 19(3), $16-29$

11. McKinsey (2000) The War for Talent. McKinsey \& Company.

12. Ordonez de \& Pablos, P. (2004) Human resource management systems and their role in the development of strategic resources: empirical evidence. Journal of European Industrial Training, 28(6/7), 474 - 489

13. Powell, M \& Lubitsh, G. (2007) Courage in the face of extraordinary talent: Why talent management has become a leadership issue. Strategic HR Review, 6(5), 24-27.

14. Russell, J.S., Terborg, J.R. and Powers, M.L. (1985) Organisational performance and organisational level training and support. Personnel Psychology, 38, 849 $-863$

15. Terpstra, D.E. and Rozell, E.J. (1993) The relationship of staffing practices to organisational level measures of performance. Personnel Psychology, 46, $27-48$

16. Van Djik, H. (2008) The talent management approach to human resources management: attracting and retaining the right people. https://repository.up.ac.za/upspace/handle/2263/8823 www. up.ac.za 